\title{
Comparison of the performance of three PCR assays for the detection and differentiation of Theileria orientalis genotypes
}

Piyumali K Perera ${ }^{\text {, }}$ Robin B Gasser ${ }^{1}$, David J Pulford² , Mark A Stevenson'', Simon M Firestone', Andrew M J McFadden ${ }^{2}$ and Abdul Jabbar ${ }^{1 *}$

\begin{abstract}
Background: Oriental theileriosis is a tick-borne disease of bovines caused by the members of the Theileria orientalis complex. Recently, we developed a multiplexed tandem (MT) PCR to detect, differentiate and quantitate four genotypes (i.e., buffeli, chitose, ikeda and type 5) of T. orientalis. In this study, we used MT PCR to assess the prevalence and infection intensity of four $T$. orientalis genotypes in selected cattle herds that experienced oriental theileriosis outbreaks in New Zealand, and compared the sensitivities and specificities of MT PCR, PCR-high resolution melting (PCR-HRM) and a TaqMan ${ }^{\circledR}$ qPCR.
\end{abstract}

Methods: MT PCR, PCR-HRM analysis for T. orientalis and a TaqMan ${ }^{\circledR}$ qPCR assay for ikeda genotype were employed to test 154 and 88 cattle blood samples from North (where oriental theileriosis outbreaks had occurred; designated as Group 1) and South (where no outbreaks had been reported; Group 2) Islands of New Zealand, respectively. Quantitative data from MT PCR assay were analyzed using generalized linear model and paired-sample $t$-test. The diagnostic specificity and sensitivity of the assays were estimated using a Bayesian latent class modeling approach.

Results: In Group 1, 99.4\% (153/154) of cattle were test-positive for T. orientalis in both the MT PCR and PCR-HRM assays. The apparent prevalences of genotype ikeda in Group 1 were 87.6\% (134/153) and 87.7\% (135/154) using the MT PCR and Ikeda TaqMan ${ }^{\circledR}$ qPCR assays, respectively. Using the MT PCR test, all four genotypes of T. orientalis were detected. The infection intensity estimated for genotype ikeda was significantly higher $(P=0.009)$ in severely anaemic cattle than in those without anaemia, and this intensity was significantly higher than that of buffeli $(P<0.001)$ in the former cattle. Bayesian latent class analysis showed that the diagnostic sensitivities (97.1-98.9\%) and specificities (96.5-98.9\%) of the three PCR assays were very comparable.

Conclusion: The present findings show the advantages of using the MT PCR assay as a useful tool for in-depth epidemiological and transmission studies of $T$. orientalis worldwide.

Keywords: Theileria orientalis, Multiplexed tandem PCR, PCR-high resolution melting analysis, TaqMan ${ }^{\circledR}$ qPCR assay, Anaemia, Ikeda

\section{Background}

Theileria species (Apicomplexa: Piroplasmida; Theileriidae) are tick-transmitted intracellular protists that infect various domestic and wild ruminants worldwide [1]. Depending on their pathogenicity, Theileria species can be divided into two groups: (i) those that transform host cells (including

\footnotetext{
* Correspondence: jabbara@unimelb.edu.au

${ }^{1}$ Faculty of Veterinary and Agricultural Sciences, The University of Melbourne, Werribee, Victoria 3030, Australia

Full list of author information is available at the end of the article
}

T. annulata and T. parva) and (ii) those that do not (e.g., Theileria orientalis complex) [2]. Theileria annulata and T. parva cause the most severe forms of bovine theileriosis, whereas members of $T$. orientalis complex were recognized to usually cause a less severe form (oriental theileriosis) in cattle. However, in recent years, T. orientalis has been associated with significant outbreaks of oriental theileriosis in Australia [3,4] and New Zealand [5,6], causing pyrexia, haemolytic anaemia, productivity losses, abortions and/or mortality in dairy and beef cattle [3-8]. 
Using the sequence of the major piroplasm surface protein (MPSP) gene, to date, at least $11 \mathrm{~T}$. orientalis genotypes (designated chitose or type 1, ikeda or type 2, buffeli or type 3, types 4 to 8, and N1 to N3) have been identified globally [9]. Genotypes chitose and ikeda are proposed to be associated with severe disease in cattle in the Asia-Pacific region [3-7,10-12].

Recently, McFadden et al. [5] reported that genotype chitose was linked to an outbreak of oriental theileriosis in apparently naive cattle being transported to the northern part of the North Island of New Zealand. Since August 2012, the number of theileriosis outbreaks has increased considerably in this geographical region, and in some herds, there have been significant morbidity, mortality and productivity losses [6]. In recent studies, the identification of genotypes of $T$. orientalis was carried out on samples collected from herds with theileriosis outbreaks, and genotype ikeda was identified $[6,13]$.

Clinical signs, haematology, serology and/or molecular tools have been used for the diagnosis of theileriosis in New Zealand $[5,13]$; however, owing to increasing numbers of oriental theileriosis outbreaks in this country, there has been a need for a rapid and accurate method of identification of pathogenic genotypes of T. orientalis. Therefore, Pulford et al. (D. J. Pulford, and A. M. J. McFadden, unpublished observations) developed PCRhigh resolution melting (PCR-HRM) and $\operatorname{TaqMan}^{\circledR}$ qPCR methods employing the MPSP gene as a marker for the detection of genotype ikeda of T. orientalis in blood samples from cattle in New Zealand. Although the combined use of the PCR-HRM and TaqMan ${ }^{\circledR}$ qPCR allows the identification of the ikeda genotype, these assays do not specifically identify or differentiate other genotypes of T. orientalis (i.e., buffeli, chitose and type 5), or quantify the amount of DNA of these genotypes (D. J. Pulford, and A. M. J. McFadden, unpublished observations).

To overcome the limitations associated with conventional molecular tools (such as low diagnostic sensitivity and/or specificity, quantitation and time required for testing), Perera et al. [14] recently established and validated a multiplexed tandem PCR (MT PCR) assay for the simultaneous detection, differentiation and quantitation of four of the commonest genotypes (i.e., buffeli, chitose, ikeda and type 5) of T. orientalis in Australasia. Subsequently, Perera et al. [15] used MT PCR to estimate the prevalence and intensity of these four genotypes in cattle in 15 dairy herds in the State of Victoria, Australia, and demonstrated the utility, high performance, throughput and convenience of the assay for diagnostic and epidemiological applications. Using MT PCR, these authors were able to determine the prevalence of four common T. orientalis genotypes (i.e., buffeli, chitose, $i k e d a$ and type 5) and quantify the DNA copy number for each of these genotypes in individual cattle.
As three novel molecular-diagnostic assays have been developed independently in Australia (MT PCR) and New Zealand (PCR-HRM and TaqMan ${ }^{\circledR}$ qPCR), the aims of the present study were to: (i) employ MT PCR to estimate the prevalence and infection intensity of T. orientalis genotypes buffeli, chitose, ikeda and type 5 in selected cattle herds that had experienced oriental theileriosis outbreaks in New Zealand, and (ii) compare the sensitivities and specificities of all three assays.

\section{Methods}

\section{Farms, demographic characteristics of cattle, and blood collection}

Blood samples $(n=154)$ were collected by registered veterinarians from 103 beef (Angus, Hereford or crosses) or dairy (Friesian or crosses) herds experiencing oriental theileriosis (Group 1) in four regions (i.e., Auckland, East Cape, Northland and Waikato) from the North Island, New Zealand, between July and December 2013 (Figure 1; Table 1). The impact of this disease was recorded as 'moderate' (1-2 cattle died) on 61 farms and 'severe' ( $\geq 5$ cattle died and $>30 \%$ of the herd were anaemic) on one farm (Figure 1). Clinical signs recorded were acute death, pale vulval mucous membranes, anorexia, lethargy, tachycardia and/or tachypnoea. At necropsy, affected cattle were often jaundiced, with watery un-clotted blood in major blood vessels. Information on age and breed of cattle in each herd (where possible) was obtained. In addition to samples from cattle in herds suffering from outbreaks, blood samples $(n=88)$ from nine unaffected herds were randomly collected from asymptomatic beef cattle (Group 2) in the Southland region of the South Island, New Zealand, with no history of theileriosis (Table 1). Although ticks are abundant in North Island, there was no evidence of ticks present in the herds representing Group 2.

\section{Haematological examination}

The haematocrit (HCT) was determined for each blood sample using an automated haematology analyzer (Cell-Dyn 3700; Abbott Diagnostics Division, Illinois, USA). Based on HCT values, cattle were classified as normal (non-anaemic; > 0.24), mildly anaemic (0.15-0.24), and severely anaemic $(<0.15)$.

\section{Isolation of genomic DNA}

Individual blood samples (i.e., $40 \mu \mathrm{l}$ of blood from each individual) were diluted 1:5 in sterile Elix water, and genomic DNA was then extracted from $200 \mu \mathrm{l}$ of each sample using the QIAxtractor system and the DX universal liquid sample DNA extraction kit (Cat. No. 950107; Qiagen) using the manufacturer's protocol (eluting into $200 \mu \mathrm{l}$ ). 


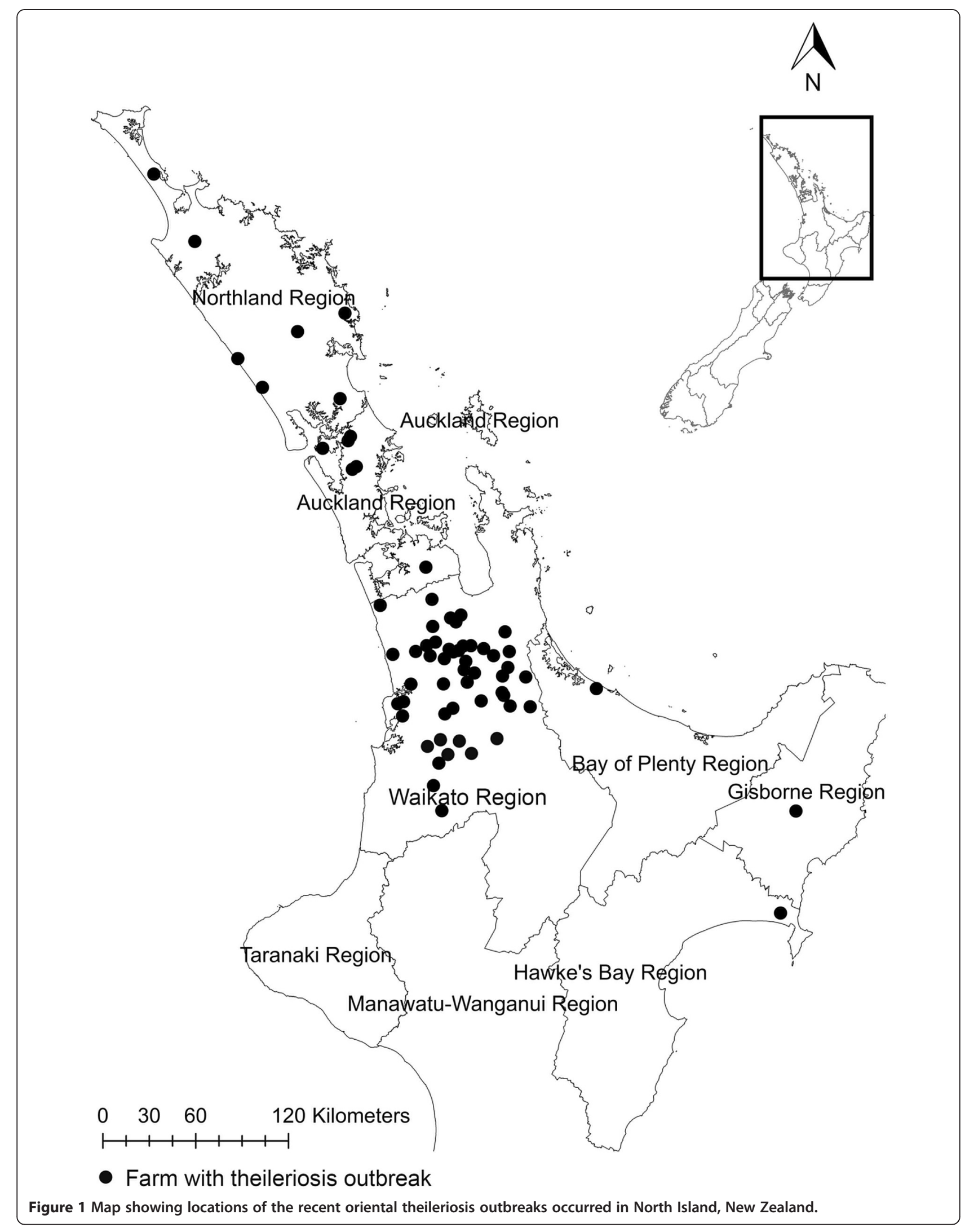


Table 1 Apparent prevalence and infection intensity with genotypes of Theileria orientalis complex in New Zealand outbreaks

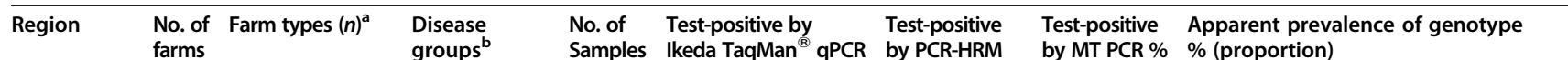
farms groups

$\begin{array}{ll}\text { Test-positive } & \text { Apparent prevale } \\ \text { by MT PCR \% } & \% \text { (proportion) }\end{array}$

(proportion) (proportion)

tested \% (proportion)

ikeda

chitose

buffeli

Mean intensity of infection

by genotype (mean no. of

DNA copies)

ikeda chitose buffeli type 5

\begin{tabular}{|c|c|c|c|c|c|c|c|c|c|c|c|c|c|c|c|}
\hline & & & & & & & & ikeda & chitose & buffeli & type 5 & ikeda & chitose & buffeli & type 5 \\
\hline \multicolumn{16}{|c|}{ North Island } \\
\hline Auckland & 13 & Beef (6)/Dairy (4) & $\mathrm{NR} / \mathrm{MO}$ & 17 & $94.1(16 / 17)$ & $100(17 / 17)$ & $100(17 / 17)$ & $94.1(16 / 17)$ & $70.6(12 / 17)$ & $100(17 / 17)$ & $29.4(5 / 17)$ & 381,134 & 15,466 & 209,763 & 10,939 \\
\hline East Cape & 8 & Beef (7)/Dairy (1) & $\mathrm{NR} / \mathrm{MO}$ & 18 & $44.4(8 / 18)$ & $100(18 / 18)$ & $100(18 / 18)$ & $44.4(8 / 18)$ & $77.8(14 / 18)$ & $83.3(15 / 18)$ & $22.2(4 / 18)$ & 64,727 & 27,164 & 68,263 & 9 \\
\hline Northland & 14 & Beef (5)/Dairy (9) & NR/MO/ANT & 32 & $100(32 / 32)$ & $100(32 / 32)$ & $100(32 / 32)$ & $100(32 / 32)$ & $87.5(28 / 32)$ & $100(32 / 32)$ & $53.1(17 / 32)$ & 237,979 & 129,868 & 159,724 & 15,823 \\
\hline Waikato & 62 & Beef (5)/Dairy (56) & NR/MO/ANT/SO & 87 & $90.8(79 / 87)$ & $98.9(86 / 87)$ & $98.9(86 / 87)$ & $90.7(78 / 86)$ & $31.4(27 / 86)$ & $100(86 / 86)$ & $3.5(3 / 86)$ & 420,479 & 57,012 & 186,854 & 859 \\
\hline Total & 97 & Beef (23)/Dairy (70) & & 154 & $87.7(135 / 154)$ & $99.4(153 / 154)$ & $99.4(153 / 154)$ & $87.6(134 / 153)$ & $52.9(81 / 153)$ & $98.0(150 / 153)$ & $19.0(29 / 153)$ & 349,271 & 70,684 & 170,786 & 11,252 \\
\hline \multicolumn{16}{|c|}{ South Island } \\
\hline Southland & 9 & Beef (9) & NR & 88 & $0 \%(0 / 88)$ & $2.3 \%(2 / 88)$ & $2.3 \%(2 / 88)$ & 0 & $100(2 / 2)$ & $100(2 / 2)$ & $100(2 / 2)$ & 0 & 6,916 & 7,694 & 22 \\
\hline
\end{tabular}

${ }^{a} n$ denotes the number of farms sampled. For some farms the farm type (dairy or beef) information were not collected.

bisease groups were categorized according to clinical signs and haematological parameters. 'NR', 'ANT', 'MO' and 'SO' denote no disease reported, anaemia negative Theileria (i.e., anaemia not observed but Theileria piroplasms were observed on blood smears), moderate outbreak (i.e., more than one animal with anaemia) and severe outbreak (i.e., with multiple deaths), respectively. 


\section{MT PCR}

This assay was conducted using primer pairs (Cat. No. 38170R; AusDiagnostics Pty Ltd, Australia) to the piroplasm surface protein ( $p 23)$ gene (genotype buffeli), MPSP gene (chitose), the first internal transcribed spacer (ITS-1) of nuclear ribosomal DNA (ikeda) and again the MPSP gene (type 5) in the Easy-Plex platform (AusDiagnostics), as described previously [14]. Following primary and secondary amplifications, the peak high resolution melting temperature for each amplicon was compared with the pre-determined reference temperatures representing individual genotypes: buffeli $\left(83.6 \pm 1.5^{\circ} \mathrm{C}\right)$, chitose $\left(82.1 \pm 1.5^{\circ} \mathrm{C}\right)$, ikeda $\left(87.4 \pm 1.5^{\circ} \mathrm{C}\right)$ and type 5 $\left(81.6 \pm 1.5^{\circ} \mathrm{C}\right)$ [14]. Randomly selected amplicons for each genotype were subjected to single-strand conformation polymorphism (SSCP) analysis and sequencing $[7,16]$.

\section{PCR-HRM}

To amplify all genotypes of T. orientalis, this assay was performed as described previously (D. J. Pulford, and A. M. J. McFadden, unpublished observations). Briefly, a region of the MPSP gene (274 bp) was amplified from genomic DNA (3 $\mu \mathrm{l})$ using the primers Th.oriMPSP-F (5'-TCCTTGTT TGCCTCGCTCTGCT-3') and Th.oriMPSP-R (5'-AGGC AGGTCTTTTTGCCGCTGA-3').

\section{$\operatorname{TaqMan}^{\circledR}$ qPCR}

To detect genotype ikeda in samples that tested positive by PCR-HRM, the Ikeda TaqMan ${ }^{\circledR}$ qPCR was used as previously described (D. J. Pulford, and A. M. J. McFadden, unpublished observations). A region of the MPSP gene of the genotype ikeda (86 bp) was amplified from genomic DNA $(2 \mu \mathrm{l})$ using the primers NZIke1-F (5'-AGT TAACGCCACCGCAGCCG-3') and the NZIke1-R (5'-AC GCGGTATCCCTCTTCGGCA-3'), using NZIkeda1-Probe ([6FAM]-CGCCTCAAACGCCAACGACG-[BHQ1]) as a specific probe. Following PCR, $\mathrm{C} t$ values were observed for each sample, and a sample was recorded as 'test-positive' if the $\mathrm{C} t$ value was $<38$ (D. J. Pulford, and A. M. J. McFadden, unpublished observations).

\section{Statistical analyses}

For MT PCR, the DNA copy numbers of individual genotypes of $T$. orientalis recorded in each blood sample was log-transformed. A generalized linear model was then used to compare the relative intensity of infection for each genotype in individual cattle among three categories of anaemia (i.e., severe anaemia, mild anaemia and no anaemia). A paired-sample $t$-test was used to compare the intensity of infection of the genotypes shown to be dominant, based on prevalence within severely, mildly or non-anaemic cattle (Group 1), using the genotype with the lowest mean DNA copy number as the reference category. The software package SPSS Statistics 22 (IBM) was used for statistical analyses; a $P$-value of $<0.05$ was considered statistically significant.

The diagnostic specificity and sensitivity of the MT PCR assay were estimated using a Bayesian latent class modeling approach $[17,18]$ as described previously [14]. Briefly, two sets of conditionally dependent tests (i.e., Set 1; MT PCR and TaqMan ${ }^{\circledR}$ qPCR for genotype ikeda only, Set 2; MT PCR and PCR-HRM for T. orientalis) were carried out on two distinct cattle populations (i.e., Groups 1 and 2) in the absence of a 'gold standard' (i.e., reference samples of known disease status). The apparent prevalence was assumed to be distinct for each population and the diagnostic specificity and sensitivity of each test was assumed to be constant across the two populations. To allow for zero-infection prevalences, the prevalence in each population was modelled as a mixture of point mass at zero and a continuous beta distribution, as described by Branscum et al. [17]. Diagnostic specificity and sensitivity of each test was assumed to be constant across the two populations. The three molecular diagnostic tests were assumed to be dependent (conditional on infection status), because they had the same biological basis, i.e., the detection of DNA of T. orientalis genotypes. Information about the diagnostic specificity and sensitivity of the MT PCR [14], and Ikeda TaqMan $^{\circledR}$ qPCR and PCR-HRM were modelled using independent and informative beta-distributions elicited from two technical experts [R. B. Gasser and A. M. J. McFadden, respectively] with knowledge of the study populations and diagnostic test performance. The technical experts were not involved in the sample collection and/or testing. Agreement statistics (prevalence-adjusted bias-adjusted Kappa, PABAK) [19] were directly calculated as model outputs. Final inferences were presented as the $50 \%, 2.5 \%$ and $97.5 \%$ quantiles of the marginal posterior distributions for each of the parameters, corresponding to a posterior median point estimate and a 95\% probability interval (95\% PI), respectively.

\section{Results}

Apparent prevalence of $T$. orientalis genotypes and estimation of infection intensity by MT PCR

In Group 1, 99.4\% (153/154) of cattle sampled from North Island were test-positive for $T$. orientalis by MT PCR, and 100\% apparent prevalence was recorded for cattle from the Auckland, East Cape and Northland regions, and $98.9 \%(86 / 87)$ in Waikato region (Table 1$)$. In Group 2 cattle, there was a low prevalence $(2.3 \%$; $2 / 88)$ of genotypes buffeli, chitose and type 5 of T. orientalis; genotype ikeda was absent (Table 1). All four genotypes (i.e., buffeli, chitose, ikeda and type 5) were detected in all four geographical regions of the North Island, and buffeli had the highest prevalence (98.0\%; 150/153), 
followed by ikeda (87.6\%; 134/153), chitose (52.9\%; 81/ $153)$ and type 5 (19.0\%; 29/153). Herds in Auckland, East Cape and Waikato had the highest prevalence of genotype buffeli while those in Northland had both genotypes $i k e d a$ and buffeli in higher prevalences. In individual cattle, multiple genotypes of $T$. orientalis were more commonly detected than single genotypes (Figure 2). Mixed infections with genotypes buffeli and ikeda showed the highest prevalence (46.4\%) followed by a combination of genotypes buffeli, chitose and ikeda (25.5\%) (Figure 2).

Although genotype buffeli was prevalent in almost all farms in North Island, the relative average intensity of infection with genotype ikeda was dominant (with an average of 349,271 DNA copies), followed by buffeli $(170,786)$, chitose $(70,684)$ and type $5(11,252)$ (Table 1$)$. With the exception of East Cape, outbreaks in all other regions of North Island showed higher infection intensity with genotype ikeda than with genotype buffeli (Table 1).

Based on HCT values (130 blood samples), cattle in Group 1 were categorized as severely anaemic $(\mathrm{HCT}<$ $0.15 ; n=49$ ), mildly anaemic (HCT $0.15-0.24 ; n=31$ ) or non-anaemic/ normal (HCT $>0.24 ; n=50$ ) (Table 2). Haematocrit values were not available for the cattle in Group 2, but were assumed to be normal given that blood had been collected from clinically normal cattle and there was no indication of $i k e d a$ or its vector being present in the region. The apparent prevalences of genotypes buffeli and ikeda were high (100\%) in severely anaemic cattle. However, in both mildly anaemic and non-anaemic cattle, the apparent prevalence of genotype buffeli was higher (96.8\% and 92\%, respectively). In nonanaemic cattle, the prevalence of genotype ikeda was lower (66\%) than that of genotypes buffeli or chitose (Table 2).

Overall the intensity of infection with genotype ikeda was higher in infected cattle in severely anaemic, mildly anaemic and non-anaemic categories (Table 2). Intensity of infection with genotype ikeda was significantly higher $(P=0.009)$ in severely anaemic cattle than that in nonanaemic cattle (Table 3 ). In mildly anaemic cattle, the intensity of infection with genotype type 5 was significantly higher $(P=0.006)$ than in non-anaemic cattle (Table 3$)$. Paired-sample $t$-test of data for severely anaemic cattle showed that intensity of infection with genotype ikeda was significantly higher than that with buffeli $(P<0.001)$ (Table 4).

\section{SSCP-coupled sequencing of MT PCR amplicons}

SSCP analysis of 50 of all 154 amplicons representing the genotypes buffeli $(n=15)$, chitose $(n=10)$, ikeda $(n=15)$ and type $5(n=10)$ showed four main profiles. Minor profile variation was detected within genotype buffeli (data not shown), which was reflected in a minute peak melting temperature difference $\left(0.8-0.9^{\circ} \mathrm{C}\right)$. DNA sequencing of amplicons revealed that a nucleotide variation of $1.4 \%$ was linked to the target region (data not shown).

Apparent prevalence of $T$. orientalis genotypes by $T$. orientalis PCR-HRM analysis and Ikeda TaqMan ${ }^{\circledR}$ qPCR

In Group 1, the prevalence of infection with all genotypes of $T$. orientalis by PCR-HRM was estimated at

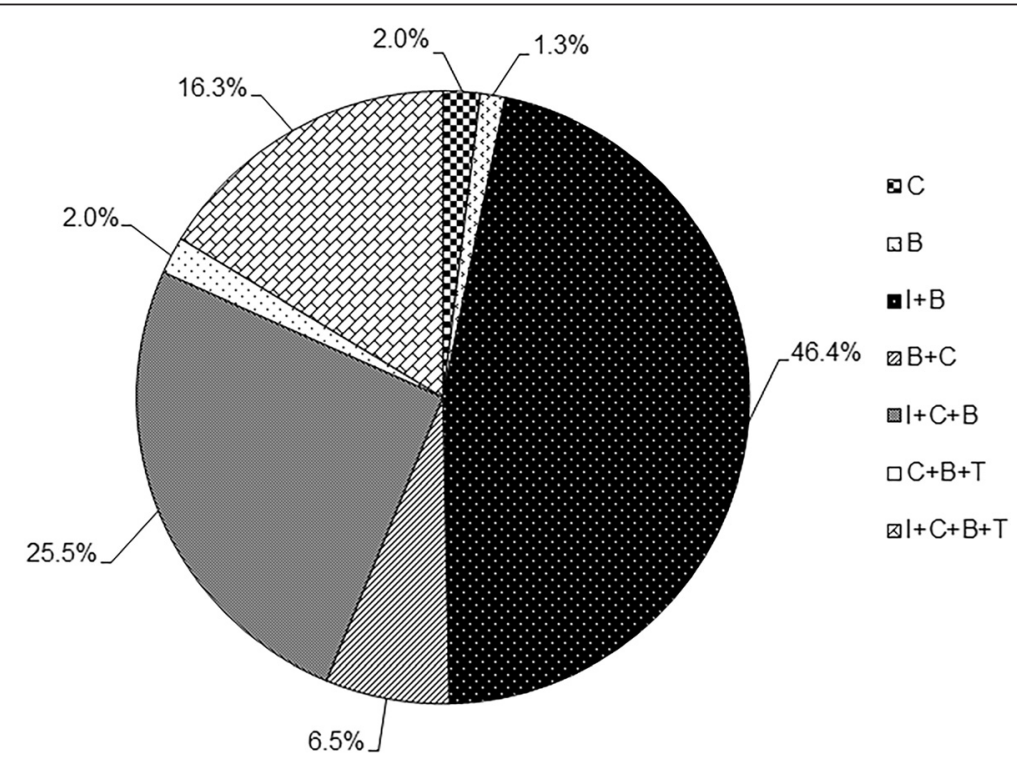

Figure 2 Prevalence of genotypes of the Theileria orientalis complex detected by the MT PCR assay. Letters ' $C$ ', ' $B$ ', 'I' and 'T' denote single infections by genotypes chitose, buffeli, ikeda and type 5, respectively. Various combinations of letters with the sign ' + ' denote mixed infections with two or more genotypes. 
Table 2 Prevalence and intensities of Theileria orientalis genotypes detected using MT PCR in three anaemic categories

\begin{tabular}{|c|c|c|c|c|c|c|c|c|}
\hline \multirow[t]{2}{*}{ Category $(n)^{\mathrm{a}}$} & \multicolumn{4}{|c|}{ Apparent prevalence of genotype \% (proportion) } & \multicolumn{4}{|c|}{ Mean intensity of infection (mean no. of DNA copies) } \\
\hline & ikeda & chitose & buffeli & type 5 & ikeda & chitose & buffeli & type 5 \\
\hline Severe anaemia ${ }^{\mathrm{b}}(49)$ & $100(49 / 49)$ & $34.7(17 / 49)$ & $100(49 / 49)$ & $8.2(4 / 49)$ & 445,347 & 68,915 & 157,443 & 88 \\
\hline Mild anaemia ${ }^{c}(31)$ & $93.5(29 / 31)$ & $38.7(12 / 31)$ & $96.8(30 / 31)$ & $16.1(5 / 31)$ & 429,380 & 167,705 & 260,844 & 9,518 \\
\hline${\text { No } \text { anaemia }^{\mathrm{d}}(50)}$ & $66(33 / 50)$ & $70(35 / 50)$ & $92(46 / 50)$ & $26(13 / 50)$ & 240,359 & 44,838 & 134,136 & 1,558 \\
\hline
\end{tabular}

${ }^{a} n$, number of animals.

${ }^{\mathrm{b}}$ Severe anaemia was defined if haematocrit value was $<0.15$.

${ }^{\mathrm{C}}$ Mild anaemia was defined if haematocrit value was $0.15-0.24$

${ }^{\mathrm{d}}$ No anaemia was defined if haematocrit value was $>0.24$.

(Haematocrit data were available for only 130 individuals of the tested 154 cattle from North Island).

99.4\% (153/154) (Table 1), and the Ct value ranged from 16.2 to 36.5 (mean $25.3 \pm 4.2$ ). Results for the TaqMan ${ }^{\circledR}$ qPCR revealed that $87.7 \%(135 / 154)$ of cattle in Group 1 were positive for genotype ikeda (Table 1), with $\mathrm{Ct}$ values ranging from 20.9 to 35.9 (mean $27.2 \pm 2.7$ ). In Group 2, only two cattle (2.3\%) were test-positive with genotype buffeli using PCR-HRM (Table 1).

\section{Comparison of performance of the three molecular} diagnostic methods

All samples that were test-positive by PCR-HRM were also test-positive by MT PCR assay for one or more genotypes of $T$. orientalis. All samples test-negative by PCR-HRM were also test-negative for T. orientalis genotypes buffeli, chitose, ikeda or type 5 by MT PCR. Of the 135 samples that were test-positive by Ikeda TaqMan ${ }^{\circledR}$ qPCR, 134 were test-positive for genotype ikeda in the MT PCR assay. The diagnostic specificity of the MT PCR detecting genotype ikeda (98.9\%; 95\% PI: 96.4, 99.8\%) was calculated to be comparable to that of the
Ikeda TaqMan ${ }^{\circledR}$ qPCR (97.4\%; 95\% PI: 95.1, 98.8\%); the diagnostic sensitivity of the MT PCR (98.0\%; 95\% PI: 94.6, 99.6\%) was also comparable to that of Ikeda TaqMan ${ }^{\circledR}$ qPCR (97.1\%; 95\% PI: 94.2, 98.8\%) using a cut-off for test positivity of $\geq 1$ DNA copies (Table 5). The diagnostic specificity (97.8\%; 95\% PI: 94.5, 99.3\%) and sensitivity (98.9\%; 95\% PI: 97.0, 99.8\%) of the MT PCR for the simultaneous detection of genotypes buffeli, chitose, ikeda and type 5 of T. orientalis were also very comparable with values calculated for PCR-HRM (96.5\%; 95\% PI: 94.3, 98.3\%; 97.6\%; 95\% PI: 95.6, 99.0\%, respectively) (Table 6). Overall, there was an excellent agreement (posterior median PABAK> 0.867 for all iterations) in results between the MT PCR and PCR-HRM assays using samples from both groups of cattle.

\section{Discussion}

This is the first application of the newly developed semiquantitative MT PCR assay [14] for the simultaneous detection and differentiation of four genotypes of $T$.

Table 3 Comparisons of intensities of four genotypes of Theileria orientalis among three anaemic categories

\begin{tabular}{|c|c|c|c|c|}
\hline \multirow[t]{2}{*}{ Genotype } & \multirow[t]{2}{*}{ Groups $(n)^{\mathrm{a}}$} & \multicolumn{3}{|c|}{ Intensity of infection (log DNA copy nos.) } \\
\hline & & Mean difference $\pm \mathrm{SE}^{\mathrm{b}}$ & $95 \% \mathrm{Cl}^{\mathrm{C}}$ & $P$-value \\
\hline \multirow[t]{3}{*}{ ikeda } & Severe anaemia $^{d}(49)$ & $0.510 \pm 0.20$ & $0.129,0.892$ & 0.009 \\
\hline & Mild anaemia ${ }^{e}(29)$ & $0.323 \pm 0.22$ & $-0.109,0.755$ & 0.143 \\
\hline & No anaemia ${ }^{f}(33)$ & Reference group & & \\
\hline \multirow[t]{3}{*}{ chitose } & Severe anaemia $^{d}(17)$ & $0.005 \pm 0.28$ & $-0.546,0.556$ & 0.986 \\
\hline & Mild anaemia ${ }^{\mathrm{e}}(12)$ & $0.238 \pm 0.32$ & $-0.386,0.861$ & 0.455 \\
\hline & No anaemia ${ }^{f}(35)$ & Reference group & & \\
\hline \multirow[t]{3}{*}{ buffeli } & Severe anaemia $^{\mathrm{d}}$ (49) & $0.120 \pm 0.14$ & $-0.153,0.393$ & 0.390 \\
\hline & Mild anaemia ${ }^{\mathrm{e}}(30)$ & $0.199 \pm 0.16$ & $-0.113,0.511$ & 0.212 \\
\hline & No anaemia ${ }^{f}(46)$ & Reference group & & \\
\hline \multirow[t]{3}{*}{ type 5} & Severe anaemia ${ }^{\mathrm{d}}(4)$ & $-0.066 \pm 0.58$ & $-1.193,1.061$ & 0.909 \\
\hline & Mild anaemia ${ }^{\mathrm{e}}(5)$ & $1.442 \pm 0.53$ & $0.405,2.479$ & 0.006 \\
\hline & No anaemia ${ }^{f}(13)$ & Reference group & & \\
\hline
\end{tabular}

${ }^{a} n$, number of animals.

${ }^{\mathrm{b}} \mathrm{SE}$, standard error.

${ }^{\mathrm{C}} \mathrm{Cl}$, confidence interval.

${ }^{d}$ Severe anaemia was defined if haematocrit value was $<0.15$.

${ }^{\mathrm{e}}$ Mild anaemia was defined if haematocrit value was $0.15-0.24$.

${ }^{\mathrm{f}} \mathrm{No}$ anaemia was defined if haematocrit value was $>0.24$. 
Table 4 Comparisons of intensities of genotypes ikeda and buffeli within each anaemic category

\begin{tabular}{|c|c|c|c|c|c|}
\hline \multirow[t]{2}{*}{ Categories $(n)^{\mathrm{a}}$} & \multirow[t]{2}{*}{ Genotypes } & \multicolumn{4}{|c|}{ Intensity of infection (DNA copy nos.) } \\
\hline & & Median $(\min , \max )^{b}$ & Mean & Differences of $\log$ mean $(95 \% \mathrm{CI})^{\mathrm{c}}$ & $P$-value \\
\hline \multirow[t]{4}{*}{ Severe anaemia $^{\mathrm{d}}(49)$} & \multirow[t]{2}{*}{ ikeda } & 252,860 & \multirow[t]{2}{*}{445,347} & \multirow[t]{2}{*}{$0.403(0.34,0.47)$} & \multirow[t]{2}{*}{$<0.001$} \\
\hline & & $(247,2242,034)$ & & & \\
\hline & \multirow[t]{2}{*}{ buffeli } & 108,368 & \multirow[t]{2}{*}{157,443} & \multirow[t]{2}{*}{ Reference group } & \\
\hline & & $(680,901,132)$ & & & \\
\hline \multirow[t]{4}{*}{ 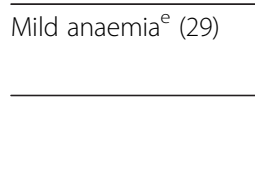 } & \multirow[t]{2}{*}{ ikeda } & 237,140 & \multirow[t]{2}{*}{429,380} & \multirow[t]{2}{*}{$0.112(-0.16,0.39)$} & \multirow[t]{2}{*}{0.408} \\
\hline & & $(1,925,2718,117)$ & & & \\
\hline & \multirow[t]{2}{*}{ buffeli } & 95,313 & \multirow[t]{2}{*}{269,257} & \multirow[t]{2}{*}{ Reference group } & \\
\hline & & $(2,456,3,698,674)$ & & & \\
\hline \multirow[t]{4}{*}{ No anaemia $^{f}(33)$} & \multirow[t]{2}{*}{ ikeda } & 74,688 & \multirow[t]{2}{*}{240,359} & \multirow[t]{2}{*}{$-0.076(-0.32,0.17)$} & \multirow[t]{2}{*}{0.532} \\
\hline & & $(387,3090,431)$ & & & \\
\hline & \multirow[t]{2}{*}{ buffeli } & 78,619 & \multirow[t]{2}{*}{141,731} & \multirow[t]{2}{*}{ Reference group } & \\
\hline & & $(1,212,1164,903)$ & & & \\
\hline
\end{tabular}

${ }^{a} n$, number of animals.

${ }^{b}$ min, minimum; max, maximum.

${ }^{\mathrm{c}} \mathrm{Cl}$, confidence interval.

${ }^{\mathrm{d}}$ Severe anaemia was defined if haematocrit value was $<0.15$.

e Mild anaemia was defined if haematocrit value was $0.15-0.24$.

${ }_{\mathrm{f}}^{\mathrm{No}}$ anaemia was defined if haematocrit value was $>0.24$.

Table 5 Diagnostic test performance of MT PCR and Ikeda TaqMan $^{\circledR}$ qPCR

\begin{tabular}{|c|c|}
\hline Outcome & Median $(95 \% \mathrm{PI})^{\mathrm{a}}$ \\
\hline \multicolumn{2}{|l|}{ MT PCR } \\
\hline Diagnostic sensitivity (\%) & $98.0(94.6,99.6)$ \\
\hline Diagnostic specificity (\%) & $98.9(96.4,99.8)$ \\
\hline \multicolumn{2}{|l|}{ Ikeda TaqMan ${ }^{\circledR}$ qPCR } \\
\hline Diagnostic sensitivity (\%) & $97.1(94.2,98.8)$ \\
\hline Diagnostic specificity (\%) & $97.4(95.1,98.8)$ \\
\hline \multicolumn{2}{|l|}{ Estimated true prevalence } \\
\hline Group $1(\%)$ & $88.1(82.5,93.1)$ \\
\hline Group $2(\%)$ & $0(0,0.12)$ \\
\hline \multicolumn{2}{|l|}{ Agreement between tests } \\
\hline PABAK in group 1 & $94.0(89.0,97.2)$ \\
\hline PABAK in group 2 & $94.1(88.0,97.7)$ \\
\hline \multicolumn{2}{|c|}{ Conditional dependence between tests ${ }^{b}$} \\
\hline$\rho+$ & $0.371(0.004,0.764)$ \\
\hline$\rho-$ & $0.226(-0.006,0.674)$ \\
\hline \multicolumn{2}{|l|}{ Model fit } \\
\hline $\mathrm{pD}$ & 7.6 \\
\hline DIC & 28.4 \\
\hline \multicolumn{2}{|c|}{$\begin{array}{l}\text { The diagnostic sensitivity of the MT PCR was defined based on a cut-off of } \geq 1 \\
\text { DNA copies. } \\
\text { aPI, probability interval. } \\
{ }^{b} \rho+\text { is the conditional correlation between MT and lkeda TaqMan }{ }^{\circledR} \text { qPCRs for } \\
\text { infected animals, and } \rho \text { - is the conditional correlation for uninfected animals. } \\
\text { PABAK = prevalence-adjusted bias-adjusted Cohen's kappa }(\kappa) \text { statistic. } \\
\text { pD = effective dimension (model complexity). } \\
\text { DIC = Deviance information criterion, a generalisation of Akaike's Information } \\
\text { Criterion (AIC). }\end{array}$} \\
\hline
\end{tabular}

orientalis in New Zealand. The MT PCR assay uses three independent markers (i.e., genotype-specific primers) in the $p 23$ gene, MPSP gene and ITS- 1 of nuclear ribosomal DNA regions for the simultaneous detection of genotypes buffeli, chitose and type 5, and ikeda, respectively. In contrast, the TaqMan ${ }^{\circledR}$ qPCR and PCR-HRM assays (D. J. Pulford, and A. M. J. McFadden, unpublished observations) both employ primers to the MPSP gene to detect genotypes ikeda and T. orientalis, respectively. Comparison of the MT PCR with the two other PCR techniques using Bayesian latent class modeling showed that the diagnostic sensitivities ( $\geq 97.1 \%$ ) and specificities $(\geq 96.5 \%)$ of the three molecular tools were comparable.

Using both MT PCR and PCR-HRM, we observed that 99.4\% (153/154) and 2.3\% (2/88) of cattle were infected with T. orientalis using samples from the North (Group 1) and South (Group 2) Islands of New Zealand, respectively. Using the MT PCR assay, we identified all four genotypes of $T$. orientalis (i.e., buffeli, chitose, ikeda and type 5) in all four regions (i.e., Auckland, East Cape, Northland and Waikato) studied on the North Island, with buffeli having the highest apparent prevalence (98.0\%). Using this assay, we were also able to detect the presence of genotypes chitose and type 5 on the South Island, not detectable by the other two tests, and to confirm the absence of genotype ikeda, in accordance with results for both MT PCR and Ikeda TaqMan ${ }^{\circledR}$ qPCR.

In 1982, James et al. [13] reported T. orientalis cases in New Zealand from both dairy and beef cattle, mostly from Wellsford (the northern-most town in the Auckland region). The detection of $T$. orientalis in Southland cattle in the present study suggests that there may have been 
Table 6 Diagnostic test performance of MT PCR and HRM analysis

\begin{tabular}{ll}
\hline Outcome & Median (95\% PI) \\
\hline MT PCR & \\
\hline Diagnostic sensitivity (\%) & $98.9(97.0,99.8)$ \\
\hline Diagnostic specificity (\%) & $97.8(94.5,99.3)$ \\
\hline PCR-HRM analysis & $97.6(95.6,99.0)$ \\
\hline Diagnostic sensitivity (\%) & $96.5(94.3,98.3)$ \\
\hline Diagnostic specificity (\%) & \\
\hline Estimated true prevalence & $98.2(95.5,99.6)$ \\
\hline Group 1 (\%) & $0(0,2.14)$ \\
\hline Group 2 (\%) & $95.2(90.2,98.0)$ \\
\hline Agreement between tests & $94.0(87.3,97.9)$ \\
\hline PABAK in group 1 & \\
\hline PABAK in group 2 & $0.301(0.006,0.715)$ \\
\hline Conditional dependence between tests ${ }^{\mathbf{b}}$ & $0.480(0.106,0.772)$ \\
\hline$\rho+$ & 12.8 \\
\hline$\rho-$ & 35.1 \\
\hline Model fit & \\
\hline pD & \\
\hline DIC & \\
\hline
\end{tabular}

The diagnostic sensitivity of the MT PCR was defined based on a cut-off of $\geq 1$ DNA copies.

${ }^{\text {aPI, }}$ probability interval.

${ }^{\mathrm{b}} \rho+$ is the conditional correlation between MT PCR and PCR-HRM outcomes for infected animals, and $\rho$ - is the conditional correlation for uninfected animals. PABAK $=$ prevalence-adjusted bias-adjusted Cohen's kappa $(\kappa)$ statistic. $\mathrm{pD}=$ effective dimension (model complexity).

$\mathrm{DIC}=$ Deviance information criterion, a generalisation of Akaike's Information Criterion (AIC).

some recent tick activity in the region, although the information on the distribution of the proposed tickvector (Haemaphysalis longicornis) of T. orientalis in New Zealand is lacking for the South Island [20]. A possible reason for the detection of $T$. orientalis in the Southland might have been the transportation of cattle from the North to the South Island, although this explanation seems unlikely, as beef cattle from Southland tested here were less than two years of age, and because the movement of young beef cattle from the North to the southern South Island for fattening is uncommon in New Zealand. This proposal and the detection of $T$. orientalis in the South Island [21] prompt a future investigation into the current distribution of $H$. longicornis on the South Island of New Zealand.

This study reports the first detection of genotype $i k e d a$ in New Zealand using ITS-1. Previously, McFadden et al. [5] reported genotype chitose in New Zealand using primers targeting the mitochondrial gene $\operatorname{cox} 3$ and a region in the nuclear ribosomal small subunit (18S). Although previous studies have identified all four genotypes (i.e., buffeli, chitose, ikeda and type 5) using conventional PCR, employing primers to the $p 23$ and MPSP genes (D. J.
Pulford, and A. M. J. McFadden, unpublished observations), the apparent prevalence of $T$. orientalis determined here is inferred to be considerably more accurate than conventional PCR, due to a 1,000 times higher analytical sensitivity of the MT PCR [14]. In addition, the MT PCR assay is able to estimate the infection intensity for each genotype based on the DNA copy number detected. These results reveal a relationship between a high intensity of genotype ikeda and severe anaemia in cattle affected by oriental theileriosis based on HCT values $(<0.15)$, suggesting that genotype ikeda is the pathogenic genotype in New Zealand, as is the case for regions in Australia $[14,15]$. The apparent absence of genotype ikeda from cattle from Southland, where no outbreaks have been reported, also provide support for this proposal. We also found that the intensity of infection with genotype type 5 was significantly higher $(P=0.006)$ in mildly anaemic cattle than in non-anaemic cattle (Table 3); however, this result should be interpreted with caution due to small sample size in each category of cattle tested here.

It appears that genotype ikeda is the main pathogenic genotype involved in oriental theileriosis in cattle in New Zealand. Although both genotypes chitose and/or $i k e d a$ were suggested to be linked to symptomatic oriental theileriosis in cattle in Australasia, based on the presence and/or prevalence of genotypes by conventional molecular diagnostic tools [3-7,10-12], the application of MT PCR in Australia to detect and estimate the infection intensities of individual $T$. orientalis genotypes provided evidence that genotype $i k e d a$ was the main pathogenic genotype present in south-eastern Australia [15]. The present study shows a similar finding for New Zealand. However, based on conventional molecular tools, McFadden et al. [5] showed that genotype chitose was associated with a varying severity of anaemia in dairy cattle infected with $T$. orientalis. Subsequently, in outbreaks of bovine theileriosis in New Zealand in 2012 and 2013, Pulford et al. (D. J. Pulford, and A. M. J. McFadden, unpublished observations) have reported, for the first time, that genotype ikeda was linked to clinical oriental theileriosis. Furthermore, Gias et al. (E. Gias, D. J. Pulford, and A. M. J. McFadden, unpublished observations) also found a relationship between higher infection intensity of the genotype ikeda and anaemia.

The present study showed that MT PCR and PCRHRM had very similar diagnostic specificities and sensitivities for the detection of genotypes buffeli, chitose, ikeda and type 5 of T. orientalis (Tables 5 and 6). In addition, MT and Ikeda TaqMan ${ }^{\circledR}$ qPCRs had similar diagnostic specificity and sensitivity for detecting genotype $i k e d a$, and the results from MT PCR were comparable to the combined results obtained by both PCR-HRM and Ikeda TaqMan ${ }^{\circledR}$ qPCR (which are the molecular tools currently used in New Zealand; D. J. Pulford, and A. M. 
J. McFadden, unpublished observations). The estimated cost per sample (including the cost for DNA extraction) by MT PCR is AUD 22, which is approximately twice that of PCR-HRM and Ikeda TaqMan ${ }^{\circledR}$ qPCR (i.e., AUD 10). MT PCR assay used here can test 12 samples per hour, whereas the time taken to test 12 samples by PCRHRM is $1.5 \mathrm{~h}$ and an additional $1.5 \mathrm{~h}$ for Ikeda TaqMan ${ }^{\circledR}$ qPCR (i.e., a total of 3 hours). Importantly, MT PCR assay is performed in a robotic platform reducing the labour, contamination and PCR inhibition involved with many conventional and qPCR assays. In addition, the analytical MT PCR assay allows a qualitative (detection and differentiation) and semi-quantitative evaluation of four distinct genotypes of $T$. orientalis at once, which cannot be achieved using the other two PCRs.

\section{Conclusion}

In conclusion, MT PCR assay used here has some important advantages over other diagnostic techniques currently used within and outside of Australasia for the detection and differentiation of $T$. orientalis. Findings from the present study provide further support for the proposal that MT PCR assay could be used to predict the risk of clinical disease developing in cattle, based on DNA copy number thresholds of pathogenic and apathogenic genotypes. Although PCR-HRM and Ikeda TaqMan ${ }^{\circledR}$ qPCR have proven to be useful diagnostic tools in a recent epidemic of oriental theileriosis in New Zealand, MT PCR allows the simultaneous detection of four common genotypes (buffeli, chitose, ikeda and type 5) of T. orientalis complex and an estimation of the intensity of infection with these genotypes, thereby making it a useful tool for in-depth epidemiological and transmission studies.

\section{Abbreviations}

ITS-1: First internal transcribed spacer; HCT: Haematocrit; MPSP: Major piroplasm surface protein; MT PCR: Multiplexed tandem PCR; PABAK: Prevalence-adjusted bias-adjusted Kappa; PCR-HRM: PCR-high resolution melting; p23: 23-kDa piroplasm surface protein; PI: Probability interval; SSCP: Single-strand conformation polymorphism.

\section{Competing interests}

The authors declare that they have no competing interests.

\section{Authors' contributions}

PP carried out the MT PCR analysis, data analyses, interpretation of data and also drafted the manuscript, with guidance from co-authors. DJP collected blood samples, extracted DNA and carried out the PCR-HRM analysis and the TaqMan ${ }^{\circledR}$ qPCR assay for ikeda genotype. MAS and SMF performed the Bayesian latent class analysis. AJ, DJP, AMJM and RBG conceived the project and participated in the study design. AJ and RBG participated in data interpretation and provided critical inputs on the draft manuscript. All authors read and approved the final manuscript.

\section{Acknowledgements}

This project was partially supported by the Department of Agriculture Fisheries and Forestry (DAFF), a Collaborative Research Grant (the University of Melbourne) (A.J.) and the Australian Research Council (ARC) (R.B.G. et al.). Funding from the CASS Foundation and The lan Potter Foundation is also gratefully acknowledged (A.J.). P.P. is a grateful recipient of the International Postgraduate Research Scholarship (IPRS) and Australian Postgraduate Award
(APA) through The University of Melbourne. We thank Dr Aaron R. Jex for allowing the use the Easy-Plex platform (AusDiagnostics Pty. Ltd., Australia), which was bought under project 1043, funded by Water Quality Research Australia, and contributions from the Melbourne Water Corporation. We thank all of the veterinary practitioners and dairy farmers from New Zealand, who assisted by collecting blood samples, and the staff in Virology at the Animal Health Laboratory Wallaceville, particularly Dr Edna Gias, for technical support. We are grateful for Dr Munir Aktas from University of Firat, Turkey, for the provision of some parasite material.

\section{Author details}

${ }^{1}$ Faculty of Veterinary and Agricultural Sciences, The University of Melbourne, Werribee, Victoria 3030, Australia. ${ }^{2}$ Investigation and Diagnostic Centres and Response, Ministry for Primary Industries, Wellington, New Zealand.

Received: 9 March 2015 Accepted: 17 March 2015

Published online: 31 March 2015

\section{References}

1. Dobbelaere DAE, McKeever DJ. World class parasites. Volume III: Theileria Boston: Kluwer academic publishers; 2002.

2. Dobbelaere DAE, Küenzi P. The strategies of the Theileria parasite: a new twist in host pathogen interactions. Curr Opin Immunol. 2004;16:524-30.

3. Izzo MM, Poe I, Horadagoda N, De Vos AJ, House JK. Haemolytic anaemia in cattle in NSW associated with Theileria infections. Aust Vet J. 2010;88:45-51.

4. Islam MK, Jabbar A, Campbell BE, Cantacessi C, Gasser RB. Bovine theileriosis-an emerging problem in south-eastern Australia? Infect Genet Evol. 2011;11:2095-7.

5. McFadden AM, Rawdon TG, Meyer J, Makin J, Morley CM, Clough RR, et al. An outbreak of haemolytic anaemia associated with infection of Theileria orientalis in naive cattle. N Z Vet J. 2011:59:79-85.

6. McFadden A, Pulford D, Lawrence K, Frazer J, van Andel M, Donald J, et al. Epidemiology of Theileria orientalis in cattle in New Zealand, Proceedings of the Annual Conference Society of Dairy Cattle Veterinarians. New Zealand: New Zealand Veterinary Association; 2013. p. 207-17.

7. Perera PK, Gasser RB, Anderson GA, Jeffers M, Bell CM, Jabbar A. Epidemiological survey following oriental theileriosis outbreaks in Victoria, Australia, on selcted cattle farms. Vet Parasitol. 2013;197:509-21.

8. Perera PK, Gasser RB, Firestone SM, Anderson GA, Malmo J, Davis G, et al. Oriental theileriosis in dairy cows causes a significant milk production loss. Parasit Vectors. 2014;7:73. doi: 10.1186/1756-3305-7-73.

9. Sivakumar T, Hayashida K, Sugimoto C, Yokoyama N. Evolution and genetic diversity of Theileria. Infect Genet Evol. 2014;27:250-63.

10. Aparna M, Ravindran R, Vimalkumar MB, Lakshmanan B, Rameshkumar P, Kumar KG, et al. Molecular characterization of Theileria orientalis causing fatal infection in crossbred adult bovines of South India. Parasitol Int. 2011;60:524-9.

11. Kamau J, de Vos AJ, Playford M, Salim B, Kinyanjui P, Sugimoto C. Emergence of new types of Theileria orientalis in Australian cattle and possible cause of theileriosis outbreaks. Parasit Vectors. 2011;4:22. doi: 10.1186/1756-3305-4-22.

12. Perera PK, Gasser RB, Jabbar A. Assessment of sequence variability in a p23 gene region within and among three genotypes of the Theileria orientalis complex from south-eastern Australia. Ticks Tick Borne Dis. 2015;6:123-8.

13. James MP, Saunders BW, Guy LA, Brookbanks EO, Charleston WA, Uilenberg G. Theileria orientalis, a blood parasite of cattle: first report in New Zealand. N Z Vet J. 1984;32:154-6.

14. Perera PK, Gasser RB, Firestone SM, Smith L, Roeber F, Jabbar A. Semi-quantitative multiplexed-tandem PCR for the detection and differentiation of four Theileria orientalis genotypes in cattle. J Clin Microbiol. 2015;53:79-87.

15. Perera PK, Gasser RB, Read E, Malmo J, Nguyen H, Nyein S, et al. Use of multiplexed tandem PCR to estimate the prevalence and intensity of Theileria orientalis genotypes in cattle from Australia. Infect Genet Evol. 2015;32:68-73.

16. Cufos N, Jabbar A, de Carvalho LM, Gasser RB. Mutation scanning-based analysis of Theileria orientalis populations in cattle following an outbreak. Electrophoresis. 2012;33:2036-40.

17. Branscum A, Gardner I, Johnson W. Estimation of diagnostic-test sensitivity and specificity through Bayesian modeling. Prev Vet Med. 2005;68:145-63.

18. World Organisation for Animal Health (OIE). Principles and methods of validation of diagnostic assays for infectious diseases, chapter 1.1.5, Manual of diagnostic tests and vaccines for terrestrial animals. 7th ed. Paris, France: World Organisation for Animal Health (OIE); 2014. 
19. Byrt T, Bishop J, Carlin JB. Bias, prevalence and kappa. J Clin Epidemiol. 1993;46:423-9.

20. Heath ACG. Zoogeography of the New Zealand tick fauna. Tuatara. 1977;23:26-36.

21. McFadden AMJ, Heath ACG, Fairley R, Trolove P, Pulford DJ. Theileria (Ikeda) associated bovine anaemia in a West Coast dairy farm. Vetscript. 2015;28:28-30

Submit your next manuscript to BioMed Central and take full advantage of:

- Convenient online submission

- Thorough peer review

- No space constraints or color figure charges

- Immediate publication on acceptance

- Inclusion in PubMed, CAS, Scopus and Google Scholar

- Research which is freely available for redistribution 